\title{
Short communication: Effect of storage and preservation on total bacterial counts determined by automated flow cytometry in bulk tank goat milk
}

\author{
D. Sierra, ${ }^{*}$ A. Sánchez, $†$ A. Contreras,$\dagger^{1}$ C. Luengo, ${ }^{*}$ J. C. Corrales, $†$ C. de la Fe, $\dagger$ I. Guirao, ${ }^{*}$ C. T. Morales, ${ }^{*}$ \\ and C. Gonzaloł \\ *Laboratorio Agroalimentario y de Sanidad Animal, Consejería de Agricultura y Agua, Comunidad Autónoma de la Región de Murcia, El Palmar, \\ 30120 Murcia, Spain \\ †Departamento de Sanidad Animal, Facultad de Veterinaria, Universidad de Murcia, 30071 Murcia, Spain \\ ‡Departamento de Producción Animal, Facultad de Veterinaria, Universidad de León, 24071 León, Spain
}

\section{ABSTRACT}

This study was designed to evaluate the effects of different storage conditions on total bacterial count (TBC) determinations made in goat bulk tank milk using an automated flow cytometry method. The storage conditions tested were storage temperature (refrigeration at 4 and $10^{\circ} \mathrm{C}$ or freezing at $-20^{\circ} \mathrm{C}$ ), the use of a preservative (no preservative, NP; azidiol, AZ; or bronopol, BR), and the age of the milk samples for each analytical condition (storage times at $4^{\circ} \mathrm{C}$ : from 0 $\mathrm{h}$ to $5 \mathrm{~d}$ for $\mathrm{NP}$; and from $0 \mathrm{~h}$ to $22 \mathrm{~d}$ for $\mathrm{AZ}$ and $\mathrm{BR}$; storage times at $10^{\circ} \mathrm{C}$ : from $24 \mathrm{~h}$ to $2 \mathrm{~d}$ for $\mathrm{NP}$ and from $24 \mathrm{~h}$ to 22 for $\mathrm{AZ}$ and $\mathrm{BR}$; storage times at $-20^{\circ} \mathrm{C}$ : from $24 \mathrm{~h}$ to $22 \mathrm{~d}$ for NP, AZ, and BR). Significant effects on individual bacterial count (IBC) variation were shown by the bulk tank milk sample, preservative, storage temperature, interaction preservative $x$ storage temperature, and milk age within the interaction preservative $\times$ storage temperature. In preserved samples, the highest IBC were obtained for AZ and the lowest counts were obtained in samples preserved with BR. Because of the variation in IBC recorded in BR-preserved samples, we recommend that BR should not be used for TBC determinations using the automated flow cytometry method. The NP samples stored at 4 and $10^{\circ} \mathrm{C}$ showed significantly higher IBC at $24 \mathrm{~h}$ postcollection, also invalidating these analytical conditions for TBC analyses. The practical implications of our findings are that goat milk samples preserved with $\mathrm{AZ}$ and stored at 10 or $4^{\circ} \mathrm{C}$ are appropriate for TBC by the BactoScan flow cytometry method for up to $24 \mathrm{~h}$ and $11 \mathrm{~d}$ postcollection, respectively.

Key words: goat milk, total bacterial count, BactoScan flow cytometry, milk preservative

Received December 19, 2008.

Accepted July 7, 2009.

${ }^{1}$ Corresponding author: acontrer@um.es
The total bacterial count (TBC) of bulk tank milk is an important tool used to monitor milk quality in dairy goats and sheep (Muehlherr et al., 2003). Because of its implications for milk quality and food safety, the TBC is regulated according to the official milk standards of the different countries. In the European Union, the limits established (Regulation EC No. 853/2004; European Union, 2004) for sheep and goat milk used in dairy products are $1,500 \times 10^{3} \mathrm{cfu} / \mathrm{mL}$ for milk subjected to heat treatment and $500 \times 10^{3} \mathrm{cfu} / \mathrm{mL}$ for milk not subjected to heat treatment. In countries outside Europe, including the United States, TBC limits established for goat and sheep milk are the same as for cow milk (i.e., $100 \times 10^{3} \mathrm{cfu} / \mathrm{mL}$ in the United States; PMO, 2007).

In milk-testing laboratories, the $\mathrm{TBC}$ is routinely determined using automated flow cytometry (FC) devices. In the FC method, the bacteria are stained with a specific DNA/RNA fluorescent dye (ethidium bromide) and counted by the capture of the light pulses excited by a laser source into a flow cell. The FC technique expresses the TBC results in units defined as individual bacterial counts (IBC), which need to be converted into the scale of the reference method (cfu/ $\mathrm{mL}$ ). Several authors have explored the relationship between IBC and colony-forming units (Ninane et al., 2000; Suhren and Walte, 2000; Bolzoni et al., 2001; Tomaska et al., 2006).

Currently, preservatives are added to milk samples before testing for payment-by-quality schemes, official control of milk quality, and dairy herd improvement programs. Several preservation strategies are used for milk samples destined to undergo SCC using fluoro-optoelectronic counters (IDF, 2006) or the determination of milk fat, protein, and lactose contents by mid-infrared measurements (IDF, 2000). The effects of these preservatives on goat milk SCC, composition (Sánchez et al., 2005), and milk freezing-point determinations (Sánchez et al., 2007) have also been assessed. Analytical conditions affecting automatic TBC determinations have been evaluated in cow (Barcina et al., 1987; Suhren and 
Table 1. Composition and total bacterial counts (individual bacterial count, IBC, and $\mathrm{cfu} / \mathrm{mL}$ ) of the bulk tank milk samples (analyses were performed in duplicate)

\begin{tabular}{lccrrc}
\hline Item & $\mathrm{n}$ & Mean & $\mathrm{SD}$ & Minimum & Maximum \\
\hline Freezing point, $\mathrm{m}^{\circ} \mathrm{C}$ & 35 & -557 & 2.8 & -552 & -561 \\
$\mathrm{SCC}, \times 10^{3}$ cell $/ \mathrm{mL}$ & 35 & 1,638 & 180 & 1,374 & 1,971 \\
Nonfat dry matter, $\%$ & 35 & 8.883 & 0.102 & 8.660 & 9.010 \\
DM, $\%$ & 35 & 14.658 & 0.614 & 13.560 & 15.490 \\
Fat, $\%$ & 35 & 5.693 & 0.517 & 4.840 & 6.380 \\
Total protein, $\%$ & 35 & 3.530 & 0.054 & 3.420 & 3.590 \\
Lactose, $\%$ & 35 & 4.618 & 0.045 & 4.510 & 4.680 \\
$\mathrm{pH}$ & 35 & 6.695 & 0.019 & 6.670 & 6.740 \\
LogIBC $/ \mathrm{mL}_{\text {Log cfu } / \mathrm{mL}^{1}}$ & 35 & 6.582 & 0.497 & 5.710 & 7.297 \\
Colony-forming units, $\times 10^{3} / \mathrm{mL}$ & 35 & 5.930 & 0.386 & 5.255 & 6.486 \\
\hline
\end{tabular}

${ }^{1}$ Colony-forming units were calculated using the model defined by Spanish government: $\mathrm{y}=0.776 \mathrm{x}+0.823$, where $\mathrm{y}=\log \mathrm{cfu} / \mathrm{mL}$ and $\mathrm{x}=\log \mathrm{IBC} / \mathrm{mL}$ (Ministerio de la Presidencia, 2008).

Walte, 2000) and sheep milk (Elizondo et al., 2007). However, the most adequate conditions for the instrumental determination of TBC in goat milk have not yet been determined and neither have the main sources of analytical variation in this species.

The present study was designed to determine the effects of storage temperature, storage time, and preservative used on TBC values, and its repeatability, obtained by automated FC in bulk tank samples of goat milk.

Thirty-five 1,500-mL bulk tank milk samples were obtained from 35 herds of machine-milked MurcianoGranadina goats. All samples were kept at $4^{\circ} \mathrm{C}$ and immediately transported to the laboratory (Laboratorio Agroalimentario y de Sanidad Animal, Murcia, Spain) where aliquots were immediately prepared. Each sample was divided into eighty $18-\mathrm{mL}$ aliquots $(\mathrm{n}=$ 2,800 ), using a $34 \times 43 \mathrm{~mm}$ polyethylene container, and 79 were assigned to different experimental groups. The 3 preservative treatments tested were no preservative (NP), azidiol (AZ), or bronopol (BR). For each preservative treatment, 10 aliquots each were stored at 10 and $-20^{\circ} \mathrm{C}$, and 11 aliquots were stored at $4^{\circ} \mathrm{C}$. However, for the NP treatment, we tested only 2 aliquots stored at $10^{\circ} \mathrm{C}, 5$ aliquots at $4^{\circ} \mathrm{C}$, and 10 aliquots at $-20^{\circ} \mathrm{C}$. The storage times tested at $4^{\circ} \mathrm{C}$ were 0 and 24 $\mathrm{h}$, and 2,3 , and $5 \mathrm{~d}$ for $\mathrm{NP}$ and 0 and $24 \mathrm{~h}$, and $2,3,5$, $7,9,11,14,18$, and $22 \mathrm{~d}$ for $\mathrm{AZ}$ and $\mathrm{BR}$. The storage times considered at $10^{\circ} \mathrm{C}$ were $24 \mathrm{~h}$ and $2 \mathrm{~d}$ for $\mathrm{NP}$, and $24 \mathrm{~h}$ and $2,3,5,7,9,11,14,18$, and $22 \mathrm{~d}$ for the other 2 preservation treatments. The storage times tested at $-20^{\circ} \mathrm{C}$ were $24 \mathrm{~h}$ and $2,3,5,7,9,11,14,18$, and $22 \mathrm{~d}$ for NP, AZ, and BR. For the preparation of AZ, $1.8 \mathrm{~g}$ of sodium azide, $0.075 \mathrm{~g}$ of chloramphenicol, $1 \mathrm{~mL}$ of ethanol, and $4.5 \mathrm{~g}$ of sodium citrate pentahydrate were dissolved in $100 \mathrm{~mL}$ of distilled water, to which $0.035 \mathrm{~g}$ of bromophenol blue was added as a colorant. Bronopol was prepared by dissolving $5 \mathrm{~g}$ of 2-bromo-2-nitro-1,3- propanediol (Sigma-Aldrich, St. Louis, MO; reference 134708 ) in $100 \mathrm{~mL}$ of distilled water and adding 0.05 $\mathrm{g}$ of methylene blue as a colorant. Preservatives were added at $80 \mu \mathrm{L} / 20 \mathrm{~mL}$ of milk for BR (final milk concentration of $0.020 \mathrm{~g} / 100 \mathrm{~mL}$ ) and at $66 \mu \mathrm{L} / 20 \mathrm{~mL}$ of milk for AZ (final milk concentration of $0.006 \mathrm{~g}$ of sodium azide $/ 100 \mathrm{~mL}$ ).

In one aliquot of each bulk tank milk sample, milk composition and SCC were determined in duplicate using a CombiFoss 6000 FC apparatus (Foss Electric, Hillerød, Denmark). Table 1 shows the composition of the 35 original bulk tank milk samples used. A microbiological inhibitor test (Delvotest MCS, DSM Food Specialties, Delft, the Netherlands) was used to screen for antimicrobial drugs in these samples.

In all aliquots, TBC were determined in duplicate $(2$ consecutive determinations on each aliquot) using an automated flow cytometer (BactoScan FC, Foss Electric). Following Cassoli et al. (2007), results were expressed in individual bacterial counts per milliliter and log-transformed. Before and during the experiments, the equipment was subjected to interlaboratory quality control tests by a reference laboratory (J. Hüfner, Hergatz, Germany).

Comparison of the least squares means was carried out using the GLM procedure implemented in the SAS 6.11 software package (SAS Institute, 1996) according to the model, in which all the effects studied were fixed:

$$
\mathrm{Y}_{\mathrm{ijkl}}=\mu+\mathrm{B}_{\mathrm{i}}+\mathrm{S}_{\mathrm{j}}+\mathrm{P}_{\mathrm{k}}+\mathrm{SP}_{\mathrm{jk}}+\mathrm{A}_{\mathrm{l}(\mathrm{jk})}+\mathrm{e}_{\mathrm{ijk} \mathrm{k}} \text {, }
$$

where $Y_{\mathrm{ijkl}}=$ the dependent variable, that is, $\log \mathrm{IBC} /$ $\mathrm{mL} ; \mu=$ the mean; $\mathrm{B}_{\mathrm{i}}=$ the effect of the bulk tank milk sample $(\mathrm{n}=35) ; \mathrm{S}_{\mathrm{j}}=$ the effect of the storage temperature ( 3 levels: 4,10 , and $-20^{\circ} \mathrm{C}$ ); $\mathrm{P}_{\mathrm{k}}=$ the effect of the preservative (3 levels: NP, AZ, and BR); $\mathrm{SP}_{\mathrm{jk}}$ $=$ the effect of the interaction storage temperature $\times$ 
Table 2. Analysis of variance of variations in $\log \mathrm{IBC} / \mathrm{mL}^{1}$

\begin{tabular}{lrrr}
\hline Source of variation & df & \multicolumn{1}{c}{$F$} & $P$-value \\
\hline Bulk tank milk sample & 34 & $1,331.70$ & $<0.0001$ \\
Preservative & 2 & $10,755.80$ & $<0.0001$ \\
Storage temperature & 2 & $3,297.61$ & $<0.0001$ \\
Preservative $\times$ storage temperature & 2 & $1,883.56$ & $<0.0001$ \\
Milk age within interaction preservative $\times$ storage temperature & 70 & 99.34 & $<0.0001$ \\
\hline
\end{tabular}

${ }^{1} \mathrm{IBC}=$ individual bacterial count.

preservative; $A_{1(j \mathrm{k})}=$ the effect of milk age within the interaction storage temperature $\times$ preservative (storage times at $4^{\circ} \mathrm{C}: 0,1,2,3$, and $5 \mathrm{~d}$ for $\mathrm{NP}$; and $0,1,2,3,5$, $7,9,11,14,18$, and $22 \mathrm{~d}$ for $\mathrm{AZ}$ and $\mathrm{BR}$; storage times at $10^{\circ} \mathrm{C}: 1$ and $2 \mathrm{~d}$ for $\mathrm{NP}$ and $1,2,3,5,7,9,11,14,18$, and $22 \mathrm{~d}$ for $\mathrm{AZ}$ and $\mathrm{BR}$; storage times at $-20^{\circ} \mathrm{C}$ of 1 , $2,3,5,7,9,11,14,18$, and $22 \mathrm{~d}$ for $\mathrm{NP}, \mathrm{AZ}$ and $\mathrm{BR}$ ); and $\mathrm{e}_{\mathrm{ijkl}}=$ the random residual effect.

For each analytical condition, the standard deviation of repeatability $\left(\mathbf{s}_{\mathrm{r}}\right.$ and its relative value, $\mathrm{s}_{\mathrm{r}} \%$, where $\mathrm{s}_{\mathrm{r}} \%=\mathrm{s}_{\mathrm{r}} \times 100 / \overline{\mathrm{x}}$, and $\overline{\mathrm{x}}$ is the arithmetic mean of IBC) was calculated according to IDF standard 128A (IDF, 1999) using the formula

$$
\mathrm{s}_{\mathrm{r}}=\left(\frac{1}{2 \mathrm{q}} \sum_{\mathrm{i}=1}^{\mathrm{q}} \mathrm{w}_{\mathrm{i}}^{2}\right)^{1 / 2},
$$

where $\mathrm{q}$ is the number of samples and $\mathrm{w}_{\mathrm{i}}$ is the absolute difference between duplicate IBC determinations.

The factors bulk tank milk sample, preservative, storage temperature, interaction preservative $\times$ storage temperature, and milk age within the interaction preservative $\times$ storage temperature contributed significantly to the observed $\log \mathrm{IBC} / \mathrm{mL}$ (Table 2). Preservation strategy was the main factor that affected the $\log \mathrm{IBC} /$ $\mathrm{mL}$ in goat milk samples. As expected, the highest $(P$ $<0.001$ ) IBC were obtained in the milk samples free of preservatives $(7.312 \pm 0.006 \log \mathrm{IBC} / \mathrm{mL})$. In preserved samples, the highest $(P<0.001)$ IBC were obtained for the AZ treatment $(6.561 \pm 0.004 \log \mathrm{IBC} / \mathrm{mL})$, and the lowest $(P<0.001)$ IBC were in samples preserved with $\mathrm{BR}(6.296 \pm 0.004 \log \mathrm{IBC} / \mathrm{mL})$. Bronopol is a bactericidal preservative with a broad spectrum of antibacterial activity that causes membrane damage and could render the membrane impermeable (Stretton and Manson, 1973), possibly explaining the differences in IBC observed here between preserved samples.

The least squares mean of the $\log \mathrm{IBC} / \mathrm{mL}$ was greater $(P<0.001)$ at $10^{\circ} \mathrm{C}(7.012 \pm 0.006)$ than at $4^{\circ} \mathrm{C}(6.690$ $\pm 0.004)$ or $-20^{\circ} \mathrm{C}(6.467 \pm 0.004)$. Moreover, effects of the interaction preservation treatment $\times$ storage temperature revealed that the change in the IBC was modified by the preservation strategy in the stored samples, with the exception of BR-preserved samples stored at $10^{\circ} \mathrm{C}$ and at $-20^{\circ} \mathrm{C}$ (Table 3). When we examined the effect of milk age within the interaction preservative $\times$ storage temperature, it was possible to observe the changes experienced by IBC under different test conditions. Hence, at zero hours, no significant differences were obtained between the IBC values in $\mathrm{AZ}, \mathrm{BR}$, or NP samples stored at $4^{\circ} \mathrm{C}$. Azidiol has been proposed as the best preservative for TBC determinations using the FC method in cow milk (Suhren and Walte, 2000). The maximum concentration of sodium azide is fixed by the IDF at $0.024 \mathrm{~g} / 100 \mathrm{~mL}$ for SCC determinations (IDF, 2006 ), and at $0.03 \mathrm{~g} / 100 \mathrm{~mL}$ for the determination of fats, proteins, and lactose (IDF, 2000). Elizondo et al. (2007) assessed the efficacy of different concentrations of sodium azide in $\mathrm{AZ}$ preservative when used for the preservation of sheep milk, and noted that a concentration of $0.006 \mathrm{~g}$ of sodium azide/100 mL allowed for more precise evaluation of the bacteriological quality of raw milk using the Bactoscan 8000 (Foss Electric). Consistent with these observations, we used the least squares mean of the IBC values obtained at zero hours in the AZ-preserved samples stored at $4^{\circ} \mathrm{C}$ as a reference value $(6.527 \pm 0.020 \log \mathrm{IBC} / \mathrm{mL}$, geometric mean $\left.=3,365 \times 10^{3} \mathrm{IBC} / \mathrm{mL}\right)$. Accordingly, the least squares mean of the $\log \mathrm{IBC} / \mathrm{mL}$ recorded for the $\mathrm{AZ}$-preserved samples stored at $4^{\circ} \mathrm{C}$ did not vary significantly from 0 to $11 \mathrm{~d}$ postcollection (Table 4). These observations are consistent with results obtained in cow milk stored at $4^{\circ} \mathrm{C}$, in which the TBC of samples preserved with $\mathrm{AZ}$ at a concentration of $0.012 \mathrm{~g}$ of sodium azide/100 $\mathrm{mL}$ remained unchanged up to $15 \mathrm{~d}$ postcollection (Barcina et al., 1987). When the least squares mean of the $\log \mathrm{IBC} / \mathrm{mL}$ from AZ-preserved samples stored at $10^{\circ} \mathrm{C}$ was compared with values taken as reference (IBC recorded at $0 \mathrm{~h}$ in samples preserved with $\mathrm{AZ}$ stored at $4^{\circ} \mathrm{C}$ ), the trend was irregular during the study period, and the highest values $(P<0.01)$ were obtained at 2 , 5,11 , and more days postcollection. These results are in line with those obtained in sheep milk refrigerated at $6 \pm 2{ }^{\circ} \mathrm{C}$, in which preserving samples with $\mathrm{AZ}$ at the same concentration used in our study allowed for TBC determination over $3 \mathrm{~d}$ (Elizondo et al., 2007). When the least squares means of the $\log \mathrm{IBC} / \mathrm{mL}$ of 
Table 3. Least squares means and standard errors of $\log \mathrm{IBC} / \mathrm{mL}^{1}$ by storage temperature $\times$ preservative treatment

\begin{tabular}{llcrr}
\hline Storage temperature, ${ }^{\circ} \mathrm{C}$ & Preservative & LogIBC $/ \mathrm{mL}$ & $\mathrm{SE}$ & $\mathrm{IBC}^{2}$ \\
\hline 4 & Azidiol & $6.488^{\mathrm{a}}$ & 0.006 & 3,076 \\
& Bronopol & $6.224^{\mathrm{b}}$ & 0.006 & 1,675 \\
& None & $7.358^{\mathrm{c}}$ & 0.009 & 22,803 \\
10 & Azidiol & $6.736^{\mathrm{d}}$ & 0.006 & 5,445 \\
& Bronopol & $6.339^{\mathrm{e}}$ & 0.006 & 2,182 \\
& None & $7.962^{\mathrm{f}}$ & 0.014 & 91,622 \\
-20 & Azidiol & $6.458^{\mathrm{g}}$ & 0.006 & 2,871 \\
& Bronopol & $6.325^{\mathrm{e}}$ & 0.006 & 2,113 \\
& None & $6.617^{\mathrm{h}}$ & 0.006 & 4,139 \\
\hline
\end{tabular}

${ }^{\mathrm{a}-\mathrm{h}}$ Means within a column with different superscripts differ significantly $(P<0.001)$.

${ }^{1} \mathrm{IBC}=$ individual bacterial count.

${ }^{2}$ Geometric mean $\left(\times 10^{3} \mathrm{IBC} / \mathrm{mL}\right)$.

AZ-preserved samples stored at $-20^{\circ} \mathrm{C}$ were compared with the reference values, the lowest values $(P<0.01)$ were obtained from 7 to $22 \mathrm{~d}$ postcollection. Therefore, according to the accuracy, freezing at $-20^{\circ} \mathrm{C}$ did not add any additional benefit to the milk preserved with AZ.

Bronopol-preserved samples stored at 4 and $10^{\circ} \mathrm{C}$ for $24 \mathrm{~h}$ showed lower $(P<0.001) \log \mathrm{IBC} / \mathrm{mL}$ values $(6.343 \pm 0.0199$ and $6.312 \pm 0.0199$, respectively) compared with the $\mathrm{AZ}$ preserved samples at time zero. The reduction $(P<0.001)$ of the IBC obtained in BRpreserved and frozen samples at $24 \mathrm{~h}(6.315 \pm 0.0199$ $\log \mathrm{IBC} / \mathrm{mL}$ ) remained stable over the study period and invalidated these analytical conditions for TBC analyses. The preservation of goat milk samples with BR allows for the determination of milk constituents and SCC over long periods of storage (Sánchez et al., 2005). However, because of the different IBC obtained for the BR-preserved samples, we recommend that this pre- servative should not be used in goat milk samples for TBC determination using the automated FC method. For practical purposes, the automatic determination of SCC, composition, and TBC in the same milk sample should be performed using refrigerated and AZ-preserved samples.

The NP samples stored at 4 or $10^{\circ} \mathrm{C}$ showed significantly higher $\log \mathrm{IBC} / \mathrm{mL}$ at $24 \mathrm{~h}$ postcollection $(7.125$ \pm 0.0199 and $7.582 \pm 0.0199$, respectively). Our results are consistent with those obtained in cow milk, in which markedly increased TBC have been observed in NP samples stored at 0 to $2^{\circ} \mathrm{C}$ (Suhren and Walte, 2000). Frozen NP samples showed a significant increase in IBC at $24 \mathrm{~h}(6.665 \pm 0.0199 \operatorname{logIBC} / \mathrm{mL})$, which remained constant during the study. This could be explained by the fact that our milk aliquots were kept in heat-insulating polyethylene tubes, possibly inducing slow freezing such that bacterial growth could take place. The increased IBC recorded in the NP samples

Table 4. Least squares means of $\log$ individual bacterial count (IBC) $/ \mathrm{mL}$, geometric means $\left(\mathrm{GM}, \times 10^{3} \mathrm{IBC} / \mathrm{mL}\right)$, and standard deviations of the repeatability $\left(\mathrm{s}_{\mathrm{r}}\right.$ and $\mathrm{s}_{\mathrm{r}} \%$ ) of IBC determined by the BactoScan flow cytometry method calculated from log-transformed ( $\mathrm{s}_{\mathrm{r}}$ ) and untransformed values $\left(\mathrm{s}_{\mathrm{r}}\right.$ and $\left.\mathrm{s}_{\mathrm{r}} \%\right)$ over the study period according to the storage temperature $\left(4,10\right.$, and $\left.-20^{\circ} \mathrm{C}\right)$ for goat milk samples preserved with azidiol

\begin{tabular}{|c|c|c|c|c|c|c|c|c|c|c|c|c|c|c|c|}
\hline $\begin{array}{l}\text { Days post } \\
\text { collection }\end{array}$ & \multicolumn{5}{|c|}{$4^{\circ} \mathrm{C}$} & \multicolumn{5}{|c|}{$10^{\circ} \mathrm{C}$} & \multicolumn{5}{|c|}{$-20^{\circ} \mathrm{C}$} \\
\hline 1 & $6.560^{\mathrm{a}}$ & 3,631 & 0.015 & 229 & 3.69 & $6.579^{\mathrm{a}}$ & 3,793 & 0.011 & 79 & 1.22 & $6.483^{\mathrm{a}}$ & 3,041 & 0.015 & 112 & 2.11 \\
\hline 2 & $6.541^{\mathrm{a}}$ & 3,475 & 0.012 & 97 & 1.63 & $6.615^{\mathrm{a}}$ & 4,130 & 0.011 & 124 & 1.76 & $6.476^{\mathrm{a}}$ & 2,992 & 0.011 & 160 & 3.06 \\
\hline 3 & $6.544^{\mathrm{a}}$ & 3,499 & 0.035 & 129 & 2.14 & $6.577^{\mathrm{a}}$ & 3,776 & 0.008 & 120 & 1.82 & $6.463^{\mathrm{a}}$ & 2,904 & 0.014 & 169 & 3.30 \\
\hline 11 & $6.462^{\mathrm{ab}}$ & 2,897 & 0.015 & 187 & 3.72 & $6.630^{\mathrm{a}}$ & 4,266 & 0.014 & 217 & 2.84 & $6.444^{\mathrm{a}}$ & 2,780 & 0.016 & 147 & 3.00 \\
\hline 14 & $6.410^{\mathrm{b}}$ & 2,570 & 0.017 & 149 & 3.25 & $6.809^{\mathrm{b}}$ & 6,442 & 0.024 & 472 & 4.87 & $6.451^{\mathrm{a}}$ & 2,825 & 0.016 & 140 & 2.83 \\
\hline 18 & $6.426^{\mathrm{b}}$ & 2,667 & 0.021 & 154 & 3.24 & $6.917^{\mathrm{c}}$ & 8,260 & 0.010 & 282 & 2.36 & $6.450^{\mathrm{a}}$ & 2,818 & 0.014 & 179 & 3.61 \\
\hline 22 & $6.411^{\mathrm{b}}$ & 2,576 & 0.047 & 343 & 7.34 & $7.448^{\mathrm{d}}$ & 28,054 & 0.017 & 875 & 2.85 & $6.446^{\mathrm{a}}$ & 2,793 & 0.018 & 224 & 4.61 \\
\hline
\end{tabular}

${ }^{\mathrm{a}-\mathrm{d}}$ Means within a column with different superscripts differ significantly $(P<0.01)$.

${ }^{1} \mathrm{SEM}$ of $\mathrm{LSM}=0.0199$. 
precludes their use for TBC at all the storage temperatures examined here.

Table 4 shows the $\mathrm{s}_{\mathrm{r}}$ values calculated from the logtransformed $\left(\mathrm{s}_{\mathrm{r}}\right)$ and nontransformed $\left(\mathrm{s}_{\mathrm{r}}\right.$ and $\left.\mathrm{s}_{\mathrm{r}} \%\right)$ variable in our IBC repeatability study for all the study times in AZ-preserved samples. In all the preservation strategies examined, $\mathrm{s}_{\mathrm{r}}$ ( $\log$ units) were similar to those reported by other authors for raw cow milk (Ninane et al., 2000; Suhren and Walte, 2000; Bolzoni et al., 2001) and sheep milk (Tomáska et al., 2006) and always $<0.05$, which is the mean value of the BactoScan FC (Foss Electric) provided by the manufacturer. The mean $\mathrm{S}_{\mathrm{r}}$ recorded were $0.015,0.021$, and 0.014 for the NP, AZ-preserved, and BR-preserved milk samples, respectively, refrigerated at $4^{\circ} \mathrm{C} ; 0.016,0.014$, and 0.018 , respectively, for samples refrigerated at $10^{\circ} \mathrm{C}$; and $0.015,0.015$, and 0.026 , respectively, for samples frozen at $-20^{\circ} \mathrm{C}$.

Absolute $\mathrm{s}_{\mathrm{r}}$ values were proportional to the mean IBC recorded for all the ages of milk except for the frozen samples preserved with BR, which showed higher $\mathrm{S}_{\mathrm{r}}$ than frozen samples preserved with AZ. As in the case of the $\mathrm{s}_{\mathrm{r}}$ ( $\log$ units), relative values of the standard deviations of repeatability $\left(\mathrm{s}_{\mathrm{r}} \%\right)$ were similar for both the preserved and nonpreserved milk samples. Accordingly, the $\mathrm{s}_{\mathrm{r}}\left(\log\right.$ units) and $\mathrm{s}_{\mathrm{r}} \%$ recorded here for the IBC were adequate, indicating that the BactoScan FC measurements were reliably repeatable for goat milk samples stored under the analytical conditions assessed.

In conclusion, the use of samples preserved with $\mathrm{AZ}$ stored at 10 or $4^{\circ} \mathrm{C}$ are appropriate for TBC determinations by the BactoScan FC method for up to $24 \mathrm{~h}$ and $11 \mathrm{~d}$ postcollection, respectively.

\section{ACKNOWLEDGMENTS}

This study was supported by project AGL200603105GAN, financed by the Dirección General de Investigación (Spanish Ministry of Education and Science) and Project 05693/PI/07, financed by the Fundación SENECA (Agencia Regional de Ciencia y Tecnología de la Región de Murcia, Spain).

\section{REFERENCES}

Barcina, Y., M. A. Zorraquino, J. Pedauye, G. Ros, and F. Rincon. 1987. Azidiol as a preservative for milk samples. An. Vet. (Murcia) 3:65-69.

Bolzoni, G., A. Marcolini, and G. Varisco. 2001. Evaluation of the Bactoscan FC. 2. Stability, repeability, carry-over and linearity. Milchwissenschaft 56:318-321.
Cassoli, L. D., P. F. Machado, A. C. De Oliveira, and A. Coldebella. 2007. Correlation study between standard plate count and flow cytometry for determination of raw milk total bacterial count. Int. J. Dairy Technol. 60:44-48.

Ministerio de la Presidencia. 2008. Real Decreto 1728/2007, de 21 de diciembre, por el que se establece la normativa básica de control que deben cumplir los operadores del sector lácteo y se modifica el Real Decreto 217/2004, de 6 de febrero, por el que se regulan la identificación y registro de los agentes, establecimientos y contenedores que intervienen en el sector lácteo, y el registro de los movimientos de la leche. Boletin Oficial del Estado 15:3508-3519.

Elizondo, J., A. Aldunate, P. Ezcurra, I. Gallego, E. Saigos, E. Ulayar, and J. M. Izco. 2007. Efficiency of the proportion of azidiol on preservation in ewe's milk samples for analysis. Food Contr. 18:185-190.

European Union. 2004. Regulation (EC) No 853/2004 of the European Parliament and of the Council of 29 April 2004 laying down specific hygiene rules for on the hygiene of foodstuffs. Off. J. L 139:55.

IDF (International Dairy Federation). 1999. Definition and evaluation of the overall accuracy of indirect methods of milk analysis application to calibration procedure and quality control in the dairy laboratory. FIL-IDF Standard no. 128A. IDF, Brussels, Belgium.

IDF (International Dairy Federation). 2000. Whole Milk, Determination of milkfat, protein and lactose content. Guidance on the operation of mid-infrared instruments. FIL-IDF Standard no. 141C. IDF, Brussels, Belgium.

IDF (International Dairy Federation). 2006. Milk-enumeration of somatic cells. Part 2: Guidance on the operation of fluoro-optoelectronic counters. FIL-IDF Standard no. 148-2 (E). IDF, Brussels, Belgium.

Muehlherr, J. E., C. Zweifel, S. Corti, J. E. Blanco, and R. Stephan. 2003. Microbiological quality of raw goat's and ewe's bulk tank milk in Switzerland. J. Dairy Sci. 86:3849-3856.

Ninane, V., K. De Reu, R. Oger, W. Reybroeck, and A. Guyot. 2000. Évaluation du Bactoscan FC pour la numération des bactéries du lait cru. Lait 80:527-538.

PMO. 2007. Grade "A" Pasteurized Milk Ordinance. Public Health Service, Food and Drug Administration, U.S. Department of Health and Human Services, Washington, DC. http://www.mass. gov/Eeohhs2/docs/dph/environmental/foodsafety/grade_a_ milk_ordinance.pdf Accessed Oct. 20, 2008.

Sánchez, A., D. Sierra, C. Luengo, J. C. Corrales, C. de La Fe, C. T. Morales, A. Contreras, and C. Gonzalo. 2007. Evaluation of the MilkoScan FT 6000 milk analyzer for determining the freezing point of goat's milk under different analytical conditions. J. Dairy Sci. 90:3153-3161.

Sánchez, A., D. Sierra, C. Luengo, J. C. Corrales, C. T. Morales, A. Contreras, and C. Gonzalo. 2005. Influence of storage and preservation on Fossomatic cell count and composition of goat milk. J. Dairy Sci. 88:3095-3100.

SAS Institute. 1996. SAS/STAT Software Changes and enhancements through release 6.11. SAS Inst., Inc., Cary, NC.

Stretton, R. J., and T. W. Manson. 1973. Some aspects of the mode of action of the antibacterial compound bronopol (2-bromo-2nitropropan-1,3-diol). J. Appl. Bacteriol. 36:61-76.

Suhren, G., and H. G. Walte. 2000. First experiences with automatic flow cytometric determination of total bacterial count in raw milk. Bull. Int. Dairy Fed. 358:36-48.

Tomáska, M., G. Suhren, O. Hanus, H. G. Walte, A. Slottova, and M. Hofericova. 2006. The application of flow cytometry in determining the bacteriological quality of raw sheep's milk in Slovakia. Lait $86: 127-140$. 